\title{
Morphology of the first zoea of the hermit crab Pagurus edwardsi (Dana, 1852), (Decapoda: Anomura: Paguridae) obtained in the laboratory
}

\author{
Morfología de la primera zoea del cangrejo ermitaño Pagurus edwardsi (Dana 1852), \\ (Decapoda: Anomura: Paguridae) obtenidas en el laboratorio \\ Jorge Rivera $\mathbf{M}^{1}$ \\ ${ }^{1}$ Escuela de Ciencias Marítimas y Ambientales, Universidad del Mar \\ Sede Iquique-Chile Av. La Tirana 4802 Iquique, Chile \\ jorge.rivera@udelmarnorte.cl
}

\begin{abstract}
Resumen.-Se describe e ilustra el primer estadio zoea de Pagurus edwardsi. Las larvas se obtuvieron a partir de dos hembras ovígeras capturadas en el norte de Chile. La primera zoea de Pagurus edwardsi es similar a las descritas para $P$. imafukui, caracterizándose por la forma del telson, las puntas del endopodo antenal y por procesos posterolaterales cortos en los segmentos abdominales. Se discuten y comparan las
\end{abstract}

principales características morfológicas de los primeros estadios zoea del género Pagurus y con los otros géneros de Paguridae reportados en aguas chilenas.

Palabras clave: Pagurus edwardsi, Paguridae, larvas, morfología, descripción

\section{Introduction}

The hermit crabs from the Chilean waters are composed of 19 species, distributed in the continental shelf as well as in the oceanic islands (Guzmán 2004). Six of these species belong to Diogenidae, six belong to Parapaguridae and seven to Paguridae. The latter constitutes the genera Pagurus, Propagurus and Porcellanopagurus. In Chile there are currently five recognized species in the genus Pagurus: Pagurus perlatus (H. Milne Edwards), P. villousus (Nicolet), P. comptus (White), P. delsolari Haig and P. edwardsi (Dana) (Haig 1955, 1974, Retamal 1981, 1994, Guzmán 1999). Of these species, Pagurus edwardsi is the only one that is commonly distributed in the intertidal zone, from Callao, Peru to Ancud, Chile, (Haig 1955, Retamal 1981, 1994), and is abundant in the rocky intertidal regions of northern Chile. The hermit crabs have been recorded from Chilean waters (Haig 1955, Guzmán 1999, Guzmán 2004). The larval stages of the hermit crabs are abundant in the meroplankton of coastal Chilean waters (Palma 1976, 1980, Mujica \& Medina 1997). Nevertheless, no description (partial or complete) of the larval stages of this family in marine water of Chile has been reported (Werhtmann \& Báez 1997).
The aims of the present study are to describe and illustrate the first zoeal stage of Pagurus edwardsi and compare this stage to those from other known species of the genus Pagurus already described in the Pacific waters.

\section{Material and methods}

Two ovigerous females of Pagurus edwardsi were collected during low tide from the intertidal of the Campus Huayquique of the Universidad Arturo Prat, Iquique, (Northern of Chile). These females were transferred to the "Anchovy Culture Laboratory", and kept in $1 \mathrm{~L}$-tank with running seawater $\left(15-16^{\circ} \mathrm{C}\right)$. The larvae were collected after hatching and reared in the in $300 \mathrm{~mL}$ plastic bowls and fed once daily with Isochrysis sp. microalgae. The larvae were fixed in 5\% formalin and preserved in $96 \%$ ethanol. Appendages were removed and examined using a Wild microscope; drawings were made with a Leitz microscope with aid of a camera lucida. Setal counts on appendages and measurements were based on the mean of ten first zoea specimens. All setal formula are listed from proximal to distal. The carapace length (CL) of zoeas was measured from the tip of rostral spine to the medial posterior 
border of the carapace. The remaining larvae were deposited in the Museo del Mar Jorge Tomicic from the Universidad Arturo Prat (MUAP).

\section{Results}

Material examined. Twenty one zoea (10 zoea measured and/ or dissected), May 25, 2004 (MUAP-ZCD: 102).

Dimension. $\mathrm{CL}=1.45 \pm 0.05 \mathrm{~mm}$, (range 1.43-1.48 mm, $\mathrm{n}=10$ )

\section{Description (Fig. 1a-k)}

-Carapace (Fig. 1a). Rostrum well developed, slightly longer than antennae, posterolateral carapace spine small and sessile eyes.

-Abdomen (Fig. 1b). Five somites; 2-5 segments with one pair of central spines flanked by two pairs of smaller spines on posterodorsal margins. Segments 2-5 with short posterolateral processes. Spine pairs and posterolateral processes increasing in size posteriorly.

-Telson (Fig. 1c). Broad posteriorly, triangular shape; posterior margin with median cleft and $7+7$ processes (1, ii, 3-7), outermost immovable naked spine, second anomuran hair (ii), and third through seventh articulated plumodenticulated processes, being the fourth the longest one; very short marginal setae between processes and on median cleft; anal spine absent.

-Antennule (Fig. 1d). Subcylindrical, distinctly bilobed, exopod fused to protopod, with three aesthetascs and one short simple setae, with one long sub terminal plumose seta (I: denoting subterminal plumose setae).

-Antenna (Fig. 1e). Scaphocerite moderately slender, with elongate distal spine, inner margin with eight plumose setae and one short seta proximally, endopod shorter than scaphocerite, with two long terminal setae, protopod with a strong spine bearing tiny denticles.

-Mandible (Fig. 1f). Asymmetrically dentate, incisor process with strong teeth and two smaller trifid teeth; molar process with a few strong teeth and a few acute small teeth, no palp bud.

-Maxillule (Fig. 1g). Endopod 3-segmented; setal formula progressing distally $1,1,3$ of which proximal seta is the shortest; coxal endite with five plumodenticulate setae marginally and two simple submarginally; basal endite with two elongate spine-like teeth armed with a few small denticles and two simple setae submarginally.

-Maxilla (Fig. 1h). Endopod bilobed with three marginal plumose setae on proximal lobe and four plumose setae (three apical plus one subapical) on distal lobe; coxal and basal endites also bilobed. Coxal endite with one submarginal and seven marginal plumose setae on proximal lobe. Distal lobe with one submarginal and three marginal plumose setae; basal endite with one submarginal and four marginal plumose setae on proximal lobe, and one submarginal and three marginal plumose setae on distal lobe; scaphognathite with five marginal plumose setae.

-First maxilliped (Fig. 1i). No coxal setae; setal formula of basipod 1, 1, 1, 3, 3; endopod 5-segmented, with setal formula of 3, 2, 1, 2, 4 + I (I: denoting dorsolateral plumose setae) plus additional fine setae on lateral margins of segments 1-3; exopod with four natatory terminal long plumose setae.

-Second maxilliped (Fig. 1j). No coxal setae; basipod with one short simple marginal seta near to distal half and two plumose setae at distal angle. Endopod 4segmented, segments 1-3 with two marginal setae, and distal segment with $4+$ I plumose setae (I denoting dorsolateral plumose setae) and additional fine setae on lateral margins of segments 2-3; exopod 2-segmeted, with four natatory terminal plumose setae.

-Third maxilliped (Fig. 1k). Exopod, 2-segmented and slightly pointed distally.

\section{Discussion}

According to the groups established by McLaughlin (1974), among the species of the Pagurus genus, $P$. edwardsi belong to the "comptus" group, nevertheless, this author indicated that this group required revision. In this sense, a comparison of the first zoeal stages some groups of Pacific Pagurus species is reported here.

The appearance of the first zoea larvae of $P$. edwardsi is similar to those of other Paguridae (Pike \& Williamson 1958, Lee \& Hong 1970, MacMillan 1971, Hong 1981, Konishi \& Quintana 1987, McLaughlin et al. 1991a, Crain \& McLaughlin 1993, McLaughlin \& Konishi 1994). 

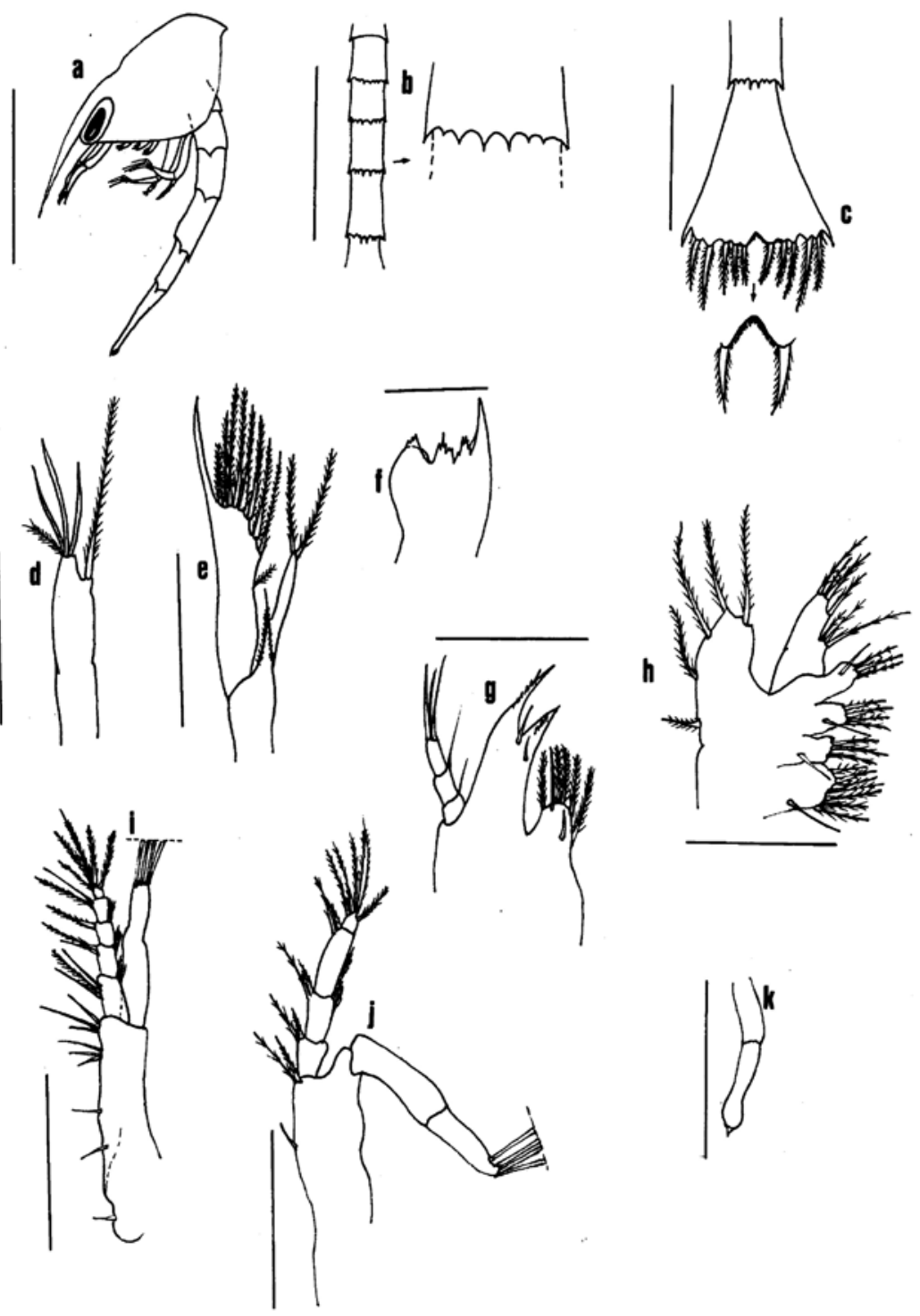

Figure 1

Pagurus edwardsi, first zoeal stage. a, lateral view; b, abdomen dorsal view; c, telson; d, antennule, e, antennae, $f$, mandible; g, maxillule; h, maxille; i, first maxilliped; j, second maxilliped, k; third maxilliped. Scale bars of a, b: $1.0 \mathrm{~mm}, \mathrm{c:} 0.60 \mathrm{~mm}$, d, e, i, j: $0.60 \mathrm{~mm}$, and f, g, h, k: $0.30 \mathrm{~mm}$

Pagurus edwardsi, primer estadio zoea. a, vista lateral; b, abdomen vista dorsal; c, telson; d, antenula, e, antena, f, mandíbula; g, maxílula; h, maxila; i, primer maxilípedo; j, segundo maxilípedo; k, tercer maxilípedo. Escala: a, b: 1.0 mm, c: 0,60 mm, d, e, i, j: $0,60 \mathrm{~mm}, \mathrm{f}, \mathrm{g}, \mathrm{h}, \mathrm{k}: 0,30 \mathrm{~mm}$ 
Table 1

Comparison of selected first zoea appendages and structures among some different species of Pagurus groups for which larval development is known in the Pacific waters

Comparación de apéndices y estructuras entre los primeros estadios zoea de algunas especies para los grupos del género Pagurus descritos en aguas del Pacífico

\begin{tabular}{|c|c|c|c|c|c|c|c|}
\hline \multirow{2}{*}{ Pagurus spp. } & \multicolumn{2}{|c|}{ antennae } & \multirow{2}{*}{$\begin{array}{c}\text { maxillule } \\
\text { endo }\end{array}$} & \multirow{2}{*}{$\begin{array}{c}\text { maxilla } \\
\text { endo }\end{array}$} & \multirow{2}{*}{$\begin{array}{l}\text { telson } \\
\text { shape }\end{array}$} & \multirow{2}{*}{$\begin{array}{l}\text { carapace } \\
\text { PLS }\end{array}$} & \multirow{2}{*}{ Ref- } \\
\hline & endo & exo & & & & & \\
\hline Provensanoi & & & & & $\operatorname{tr}$ & & \\
\hline P. vetaultae & $2 \mathrm{t}$ & $9(10)$ & $(0) 1,1,2$ & $2+3$ & et & + & [1] \\
\hline P. arenisaxatilis & $2 \mathrm{t}$ & $7(9)$ & $(0) 1,1,2$ & $2+3$ & $\operatorname{tr}$ & + & {$[2]$} \\
\hline \multicolumn{8}{|l|}{ Comptus } \\
\hline P. middendorffii & naked & 6 & $1,1,3$ & $2+4$ & et & + & [3] \\
\hline P. hirtiusculus & naked & 5 & $0,1,3$ & $3+4$ & et & + & {$[4]$} \\
\hline P. samuelis & naked & 5 & $0,1,3$ & $2+3$ & et & + & [5] \\
\hline P. edwardsi & $2 \mathrm{t}$ & $8(9)$ & $1,1,3$ & $3+4$ & $\operatorname{tr}$ & + & {$[*]$} \\
\hline \multicolumn{8}{|l|}{ Bernhandus } \\
\hline P. ochotensis & naked & 7 & $(2) 1,1,3$ & $3+4$ & et & + & {$[6]$} \\
\hline Trigonocheirus & & & & & & & \\
\hline P. trigonocheirus & bifid & 8 & $1,1,3$ & $3+4$ & et & + & [7] \\
\hline \multicolumn{8}{|l|}{ Others } \\
\hline P. lanuginosus & naked & 5 & $2,1,3$ & $2+3(4)$ & et & + & [3] \\
\hline P. brachiomastus & naked & 6 & $1,1,3$ & $3+4$ & et & + & {$[8]$} \\
\hline P. venturensis & naked & 4 & $(0) 1,1,3$ & $2(3)+3(4)$ & et & + & [9] \\
\hline P. geminus & bifid & 5 & $1,1,3$ & $3+4$ & et & + & {$[3]$} \\
\hline P. dubius & bifid & 5 & $0,1,3$ & $2+4$ & $\operatorname{tr}$ & + & [10] \\
\hline P. similis & $2 \mathrm{t}$ & 10 & $1,1,3$ & $3+3$ & $\operatorname{tr}$ & - & [11] \\
\hline P. japonicus & $2 \mathrm{t}$ & 8(9) & $1,1,3$ & $3+3$ & $\operatorname{tr}$ & - & [12] \\
\hline P. imafukui & $2 \mathrm{t}$ & $8(9)$ & $2,1,3$ & $2+3$ & $\operatorname{tr}$ & + & [13] \\
\hline Propagurus $\dagger$ & naked & 10 & $2,1,3$ & $2+4$ & $\operatorname{tr}$ & + & [14] \\
\hline Porcellanopagurus $\dagger$ & 2 & 10 & $1,1,3$ & $3+4$ & $\operatorname{tr}$ & + & [15] \\
\hline
\end{tabular}

endo., endopod; exo., exopod; t, terminal setae; () variability setation; PLS, postero-lateral spines; +, present; -, absent; et, elongated triangular; tr, triangular; †, Other Chilean Paguridae genera.

Ref., references; [*], present study; [1], McLaughlin et al. (1991a); [2], McLaughlin et al. (1991b); [3], Konishi \& Quintana, (1988); [4], McLaughlin et al. (1988); [5], MacMillan (1971); [6], McLaughlin et al. (1992); [7], Quintana \& Iwata (1987), [8], Konishi \& Quintana (1987); [9], Crain \& McLaughlin (1993); [10], Hong (1981); [11] Lee \& Hong (1970); [12], Ko \& Yang (2003); [13], McLaughlin \& Konishi (1994); [14], Komai \& Konishi (2003); [15], Robertss (1972).

P. edwardsi can be distinguished from the others Pagurus species by the variability of the some appendages such as antennule, antenna, maxillule and maxilla setation (Table 1), related with the specific differences among the genus. While, characteristics like setation on first and second maxilliped appendages and on scphognathite of maxilla, are fewer variables in the family Paguridae. This is in agreement with Guerao et al. (2001), whose study on the species of Grapsoidea larvae noted that the mouthparts setation probably only changes at higher taxonomic levels.
P. edwardsi is not similar to the first zoea of the comptus group, differing mainly for the triangular telson shape (broadly posteriorly), shorts posterolateral processes in the fifth abdominal segment and two terminal setae on the endopodal antennae tips. These characteristics are similar in P. imafukui (McLaughlin \& Konishi 1994), only differing slightly in the endopodal setal formula of the maxillule and maxilla (Table 1). The first zoea of $P$. similis and $P$. japonicus, distributed in west Pacific waters has similar setation features but it does not have posterolateral spines on the carapace (Lee \& Hong 1970, Ko \& Yang 2003). 
The presence the posterolateral spines on the carapace has been considered one of the distinguishing characteristics of Paguridae zoeae (MacDonald et al. 1957, Pike \& Williamson 1958). However, some study have shown this feature to be unreliable for characterizing the zoea of the Paguridae, as a number of species in the genera Pagurus, Lithopagurus and Munidopagurus do not bare spines on the carapace (Lee \& Hong 1970, Ko \& Yang 2003). Other Paguridae genera have very short postero lateral spines on the carapace, as for example Propagurus McLaughlin \& de Saint Laurent and Porcellanopagurus Filhol (Roberts 1972, Komai \& Konishi 2003), also represented in Chilean waters (Guzmán 1999, 2004). Those genera are similar to Pagurus edwardsi zoea here reported, exhibiting some morphological differences in their first zoeal stages, in the setal and spines numbers on the antenna, maxillule and maxilla appendages (Table 1).

Distinct and consistent adult morphological differences exist between comptus and provensanoi groups, and between other Pagurus groups; such differences have also been found in the larval development (Table 1) (McLaughlin et al. 1991a). In the present study, important morphological differences are shown among Pagurus congeneric species in the first zoeal stages, depending on the taxonomic interpretation. Apparently, the strong difference between first zoea of the Pagurus genus, based on the telson shape, endopodal antennae tip setation, posterolateral spine on the carapace, among others characters, could reflect at distinct taxonomic supraspecific status. As it has been previously suggested by other authors (MacDonald et al. 1957, Ingle 1985), noted that the Pagurus genus, as reflected by their zoeal morphology, remains a heterogenus group (McLaughlin \& Saint-Laurent 1998).

\section{Acknowledgments}

The author expresses sincere gratefulness to the Marine Biologist Marcel Fuenzalida, who facilitated the specimens for the elaboration of this article. I also thank the directors of the Anchovy Culture System from the Departamento de Ciencias del Mar, of the Universidad Arturo Prat, Profs. Gustavo Herrera and Gabriel Claramunt, for facilitating their dependencies to carry out part of this study.

\section{Literature cited}

Crain J \& P McLaughlin. 1993. Larval, postlarval and early juvenile development in Pagurus venturensis Coffin, 1957 (Decapoda: Anomura: Paguridae) reared in the laboratory, with a redescription of the adult. Bulletin of Marine Science 53(3): 985-1012.

Guerao G, CD Schubart \& JA. Cuesta. 2001. The first zoeal stages of Grapsus grapsus (Linaeus) and Geograpsus lividus (H. Milne Edwards) (Decapoda, Brachyura, Grapsidae) from the western Atlantic. Nauplius 9(2): 111121.

Guzmán G. 1999. Clave para los Crustáceos Decápodos Anomuros Marinos de Chile, 53 pp. Ediciones Campus, Universidad Arturo Prat, Iquique, Chile.

Guzmán G. 2004. Isocheles aequimanus (Dana, 1852) (Decapoda, Anomura, Paguroidea): revalidación para la carcinofauna chilena. Investigaciones Marinas, Valparaíso 32(2): 129-132.

Haig J. 1955. Reports of the Lund University Chile Expedition 1948-1949. The Crustacea Anomura of Chile. Lunds Universitets Arsskrift NF Avd. 2, 51(12): 1-68.

Haig J. 1974. Two new species of Pagurus from deep water off Peru and Chile (Decapoda, Anomura, Paguridae). Crustaceana 27(2): 119-130.

Hong SY. 1981. The larvae of Pagurus dubius (Ortmann) (Decapoda, Paguridae) reared in the laboratory. Bulletin of National Fisheries, University of Pusan 21(2): 1-11.

Ingle RW. 1985. Northeastern Atlantic and Mediterranean hermit crabs (Crustacea: Anomura: Paguroidea: Paguridae). I. The genus Pagurus Fabricius, 1775. Journal of Natural History 19: 745-769.

Ko HS \& HJ Yang. 2003. First zoea of Pagurus japonicus (Crustacea: Decapoda: Anomura: Paguridae) reared in the laboratory. Korean Journal of Biological Science 7: 11-14.

Komai T \& K Konishi. 2003. Further note on Propagurus miyakei (Baba, 1968) (Decapoda: Anomura: Paguridae), with description of its first zoea. Bulletin of Marine Science 72(3): 853-869.

Konishi K \& R Quintana. 1987. The larval stages of Pagurus brachiomastus (Thallwits, 1892) (Crustacea: Anomura) reared in the laboratory. Zoological Science 4: 349-365.

Konishi K \& R Quintana. 1988. The larval stages of three pagurid crabs (Crustacea: Anomura: Paguridae) from Hokkaido, Japan. Zoological Science 5: 463-482. 
Lee BD \& SY Hong. 1970. The larval development and growth of decapod crustacean of Korean waters. I. Pagurus similis Ortmann (Paguridae, Anomura). Publications of the Marine Laboratory from Pusan Fisheries College 3: 13-26.

MacDonald JD, RB Pike \& DI. Williamson. 1957. Larvae of the British species of Diogenes, Pagurus, Anapagurus and Lithodes (Crustacea, Decapoda). Proceedings of the Zoological Society of London 128: 209-257.

MacMillan FE. 1971. The larvae of Pagurus samuelis (Decapoda, Anomura) reared in the laboratory. Bulletin of the Southern California Academy of Sciences 70(2): 5868.

McLaughlin PA. 1974. The hermit crabs (Crustacea, Decapoda, Paguridae) of northwestern North America. Zoologische Verhandelingen 130: 1-396.

McLaughlin P, R Gore \& J Crain. 1988. Studies on the provenzanoi and others pagurid group: II. A reexamination of larval stages of Pagurus hirsutiusculus hirsutiusculus (Dana) (Decapoda: Anomura: Paguridae) reared in laboratory. Journal of Crustacean Biology 8:430-450.

McLaughlin P, R Gore \& A Harvey. 1991a. Studies on the provenzanoi and others pagurid group: IV. The larval stages of Pagurus vetaltuae Harvey \& McLaughlin, 1991 (Decapoda: Anomura: Paguridae) reared in laboratory. Journal of Crustacean Biology 11(2): 277-291.

McLaughlin P, R Gore \& A Harvey. 1991b. Studies on the provenzanoi and others pagurid group: V. The larval stages of Pagurus arenisaxatilis Harvey \& McLaughlin, 1991 (Decapoda: Anomura: Paguridae) reared in laboratory. Journal of Crustacean Biology 11(3): 416-431.

McLaughlin P, J Crain \& R Gore. 1992. Studies on the provenzanoi and others pagurid group: VI. Larval and early juvenile stages of Pagurus ochotensis Brandt (Decapoda: Anomura: Paguridae) from northeastern Pacific population, reared under laboratory conditions. Journal of Natural History 26: 507-531.

McLaughlin P \& K Konishi. 1994. Pagurus imafukui, a new species of deep-water hermit crab (Crustacea: Anomura:
Paguridae), with notes on its larvae. Publications of the Seto Marine Biological Laboratory 36(4): 211-222.

McLaughlin P \& M de Saint-Laurent. 1998. A new genus for four species of hermit crab formerly assigned to the genus Pagurus Fabricius (Decapoda: Anomura: Paguridae). Proceedings of the Biological Society of Washington 111(1): 158-187.

Mujica A \& M Medina. 1997. Larvas de crustáceos decápodos de los canales australes de Chile (41 $30^{\circ}$ ' $-46^{\circ}$ 30’S). Ciencia y Tecnología del Mar 20: 147-154.

Palma S. 1976. Meroplacton de la región de Valparaíso. Ciencia y Tecnología del Mar 2: 99-116.

Palma S. 1980. Larvas de crustáceos decápodos capturadas frente a la costa de Valparaíso. Investigaciones Marinas, Valparaíso 8: 129-144.

Pike RB \& DI Williamson. 1958. Crustacea Decapoda: Larvae. XI. Paguridae, Coenobitidae, Dromiidae, and Homolidea. Fiches d' Identification du Zooplancton /ICES 81: 1-9.

Quintana R \& F Iwata. 1987. On the larval development of some hermit crabs from Hokkaido, Japan, reared under laboratory conditions (Decapoda: Anomura). Journal of the Faculty of Science, Hokkaido University, Serie VI, Zoology 25: 25-85.

Retamal M. 1981. Catálogo ilustrado de los crustáceos decápodos de Chile. Gayana Zoología 44: 1-110.

Retamal M. 1994. Los Decápodos de Chile. Universidad de Concepción, 256 pp. Departamento de Oceanografía, Concepción, Chile.

Roberts PE. 1972. Larvae of Porcellanopagurus edwardsi Filhol, 1885 (Crustacea: Decapoda: Paguridae) from Perceverance Harbour, Campell Island. Journal of the Royal Society of New Zeland 2: 383-391

Wehrtmann I \& P Báez. 1997. Larvas y estadios tempranos de desarrollo de crustáceos decápodos de Chile. Descripciones publicadas. Investigaciones Marinas, Valparaíso 25: 263-276. 